Proceeding Paper

\title{
Formation of Monohydrocalcite in the Microbialites from La- guna de Los Cisnes (Isla Grande de Tierra Del Fuego, Chile) ${ }^{\dagger}$
}

\author{
Lyubov V. Zaytseva ${ }^{1, *}$, Olga S. Samylina ${ }^{1,2, *}$ and Alexandr A. Prokin ${ }^{3, *}$ \\ 1 Borissiak Paleontological Institute, Russian Academy of Sciences, 117647 Moscow, Russia \\ 2 Winogradsky Institute of Microbiology, Federal Research Centre "Fundamentals of Biotechnology", \\ Russian Academy of Sciences, 117312 Moscow, Russia \\ 3 Papanin Institute for Biology of Inland Waters, Russian Academy of Sciences, 152742 Borok, Russia \\ * Correspondence: 1.zaytseva@mail.ru (L.V.Z.); olga.samylina@gmail.com (O.S.S.); prokina@mail.ru (A.A.P.) \\ + Presented at the 2nd International Electronic Conference on Mineral Science, 1-15 March 2021; \\ Available online: https://iecms2021.sciforum.net/.
}

Citation: Zaytseva, L.V.; Samylina, O.S. and Prokin, A.A. Formation of Monohydrocalcite in the Microbialites from Laguna de Los Cisnes (Isla Grande de Tierra Del Fuego, Chile). Environ. Sci. Proc. 2021, 6, 2. https://doi.org/10.3390/ iecms2021-09340

Academic Editor: Paul Sylvester

Published: 25 February 2021

Publisher's Note: MDPI stays neutral with regard to jurisdictional claims in published maps and institutional affiliations.

Copyright: (c) 2021 by the authors. Licensee MDPI, Basel, Switzerland. This article is an open access article distributed under the terms and conditions of the Creative Commons Attribution (CC BY) license (http://creativecommons.org/licenses /by/4.0/).

\begin{abstract}
Monohydrocalcite $\left(\mathrm{CaCO}_{3} \cdot \mathrm{H}_{2} \mathrm{O}\right)$ is a mineral rarely found in natural environments. Here, we report finding of this mineral in the composition of the microbialites in Laguna de los Cisnes (Isla Grande, Chile), a saline alkaline lake with high $\mathrm{Mg} / \mathrm{Ca}$ ratio. We have made a detailed structural and mineralogical description of these microbialites with the use of light and scanning electron microscopy, infrared spectroscopy and X-ray analysis. The predominantly carbonate composition of microbialites was revealed. Carbonates were represented mainly by high-magnesium calcites and monohydrocalcite. Calcite and aragonite were found in minor quantities. In addition, a small amount of silicates and amorphous hydromagnesite were found. The yellowish-brown surface layer of microbialites consists of numerous crystals within a mineralized exopolysaccharide (EPS) matrix. A large number of unicellular and filamentous algae, as well as areas of released EPS, are also seen here. Below is a slimy green layer. This layer is not mineralized; it represents an "algal-bacterial mat" consisting of algae, cyanobacteria, and diatoms developed in EPS. Chisel-shaped crystals of monohydrocalcite and its amorphous spherical precursors are numerous in these upper layers. The deeper layers are mineralized; they predominantly consist of Mg-carbonates with varying degrees of Mg. Algae and cyanobacteria are decomposed or fossilized there. Thus, monohydrocalcite occurs in the composition of the microbialites, being one of the main mineral components. As in other lacustrine localities, it is formed in the presence of algae and cyanobacteria. To our knowledge, this is the first report on the discovery of monohydrocalcite in South America. This research was funded by the Ministry of Science and Higher Education of the Russian Federation.
\end{abstract}

Keywords: monohydrocalcite; saline alkaline lake; microbialites; South America

Supplementary Materials: The supplementary file is available online at https://www.mdpi.com/ article/10.3390/iecms2021-09340. 